\title{
PERBEDAAN HASIL BELAJAR SISWA KELAS X SMA MENGGUNAKAN MODEL PEMBELAJARAN KOOPERATIF TIPE STUDENT FACILITATOR AND EXPLAINING (SFE) DAN MODEL PEMBELAJARAN KONVENSIONAL PADA MATERI TRIGONOMETRI
}

\author{
Stela Ruhulessin ${ }^{1}$, Tanwey Gerson Ratumanan², Hanisa Tamalene ${ }^{3}$ \\ ${ }^{1,2,3}$ Prodi Pendidikan Matematika Fakultas Keguruan dan Ilmu Pendidikn, Universitas Pattimura \\ Jalan Ir. M. Putuhena, Kampus Unpatti, Poka, Ambon, Indonesia \\ e-mail: ${ }^{1}$ stelaruhulessin@gmail.com; ${ }^{2}$ gratumanan@yahoo.com; ${ }^{3}$ tamalene80nissa@gmail.com;
}

\begin{abstract}
Abstrak
Penelitian ini bertujuan untuk mengetahui apakah terdapat perbedaan hasil belajar siswa kelas X SMA Negeri 12 Ambon yang menggunakan model pembelajaran kooperatif tipe Student Facilitator and Explaining (SFE) dan model pembelajaran konvensional pada materi trigonometri. Tipe penelitian yang digunakan adalah tipe penelitian eksperimental (Experimental Research). Desain penelitian eksperimen yang digunakan adalah Post-Test Only Control Group Design. Teknik analisis dalam penelitian ini menggunakan analisis statistik deskriptif dan statistik uji inferensial yang terdiri dari uji normalitas data, uji homogenitas dan uji hipotesis. Data dalam pengujian tersebut diolah dengan menggunakan SPSS versi 20.0. Hasil penelitian ini adalah sebagai berikut: (1) terdapat perbedaan hasil belajar menggunakan model pembelajaran kooperatif tipe Student Facilitator and Explaining dan model pembelajaran konvensional. Hal ini dibuktikan dengan hasil atau data yang diperoleh yaitu menunjukkan nilai $\boldsymbol{t}_{\text {hitung }}=3.1128$ lebih besar dari nilai $\boldsymbol{t}_{\text {tabel }}=\mathbf{2 . 0 0 0 3}$ dan nilai Sig. (2-tailed) lebih kecil dari nilai $\boldsymbol{\alpha}=\mathbf{0 . 0 5}$ yaitu $0.002 ;(2)$ hasil belajar siswa yang menggunakan model pembelajaran kooperatif tipe Student Facilitator and Explaining lebih baik bila dibandingan dengan yang menggunakan model pembelajaran konvensional
\end{abstract}

Kata Kunci: hasil belajar, model pembelajaran kooperatif tipe student facilitator and explaining (SFE), model pembelajaran konvensional, trigonometri

\section{THE DIFFERENCE OF STUDENTS OF HIGH SCHOOL X GRADE STUDENTS USING COOPERATIVE LEARNING MODEL TYPE STUDENT FACILITATOR AND EXPLAINING (SFE) AND CONVENTIONAL LEARNING MODELS IN TRIGONOMETRY MATERIALS}

\begin{abstract}
This study aims to determine whether there are differences in learning outcomes of class X students of SMA 12 Ambon using cooperative learning model Student Facilitator and Explaining (SFE) and conventional learning models on trigonometric material. The type of research is experimental research (Experimental Research) with the Post-Test Only Control Group Design. The analysis technique is descriptive statistical analysis and inferential test statistics consisting of normality test data, homogeneity test and hypothesis test. The data are processed using SPSS version 20.0. The results of this study are (1) there are differences in learning outcomes using the cooperative learning model Student Facilitator and Explaining and conventional learning models, which shows that the value of nilai $\boldsymbol{t}_{\text {hitung }}=3.1128$ is greater than the value of $\boldsymbol{t}_{\text {tabel }}=\mathbf{2 . 0 0 0 3}$ and the value of Sig. (2-tailed) smaller than the value of $\boldsymbol{\alpha}=$ $\mathbf{0 . 0 5}$ which is 0.002 ; (2) learning outcomes of students who use the cooperative learning model Student Facilitator and Explaining type are better when compared to those using conventional learning models

Keywords: learning outcomes, cooperative learning model type student facilitator and explaining (SFE), conventional learning models, trigonometry
\end{abstract}




\section{Pendahuluan}

Pembelajaran merupakan suatu proses interaksi antara guru, siswa, dan sumber-sumber belajar yang mendorong terjadinya proses belajar. Pembelajaran dapat pula diartikan sebagai suatu upaya menciptakan kondisi yang memungkinkan siswa dapat belajar (Ratumanan, 2015). Pembelajaran yang dikelola secara baik akan dapat diharapkan dapat memberikan hasil yang baik berupa penguasaan pengetahuan dan keterampilan, serta pengembangan karakter siswa.

Dalam kaitan dengan matematika, pembelajaran seharusnya tidak hanya diarahkan agar siswa hanya menguasai pengetahuan matematika berupa fakta, konsep, prinsip, dan operasi, tetapi juga harus diarahkan untuk mengembangkan kemampuan berpikir, pemecahan masalah, dan nilai-nilai karakter. Ratumanan dan Matitaputty (2017) menyimpulkan lima kemampuan yang harus ditumbuhkembangkan melalui pembelajaran matematika, yakni:

a. Pengembangan kemampuan berpikir logis, analitis, sistematis, kritis, dan kreatif

b. Peningkatan penguasaan materi matematika

c. Pengembangan kemampuan pemecahan masalah

d. Pengembangan sikap positif terhadap matematika

e. Pengembangan kemampuan bekerjasama

Problem utama dalam pendidikan matematika saat ini adalah adanya fakta rendahnya hasil belajar matematika. Penelitian Ratumanan, dkk (2015, 2016) menunjukkan penguasaan matematika siswa di Provinsi Maluku relatif Rendah. Penelitian Ratumanan dan Laurens (2015) menunjukkan bahwa rata-rata penguasaan objek langsung matematika (konsep, prinsip, dan operasi) hanya sebesar 26,96; sedangkan rata-rata penguasaan objek tak langsung matematika (pemecahan masalah dan penalaran) hanya sebesar 31,33. Penelitian Ratumanan dan Ayall (2017) juga memperlihatkan hasil yang relatif tidak berbeda, yakni sekitar 68,75\% siswa SMP di Kota Ambon memiliki penguasaan matematika dalam kategori rendah dan sangat rendah, serta terdapat sekitar $90,625 \%$ siswa memiliki kemampuan berpikir tingkat tinggi (high order thinking) yang masuk dalam kategori rendah dan sangat rendah.

Dalam kaitannya dengan trigonometri sebagai salah satu bagian dari materi matematika sekolah, juga ditemukan banyak masalah siswa. Penguasaan siswa terhadap materi trigonometri juga relatif rendah, hal ini tercermin dari hasil observasi kelas dan hasil tes siswa. Jingga, dkk (2017) menemukan kesalahan siswa dalam menyelesaikan soal identitas trigonometri adalah karena siswa kurang memahami konsep identitas trigonometri dan konsep operasi aljabar. Demikian pula Listiyana (2012), yang menemukan bahwa kesalahan siswa pada materi trigonometri berupa kesalahan dalam menuliskan apa yang diketahui dan ditanya, kesalahan dalam menerapkan konsep aturan sinus dan cosinus, dan kesalahan dalam melakukan perhitungan. Kesalahan inilah yang menyebabkan rendahnya hasil belajar siswa.

Rendahnya hasil belajar matematika juga disebabkan oleh banyak faktor salah satunya adalah proses pembelajaran yang cenderung terpusat pada guru. Ratumanan dan Laurens (2015) menemukan beberapa faktor penyebab terkait pembelajaran, antara lain (1) Guru matematika umumnya menggunakan pendekatan mekanistik dan mengabaikan aspek kontekstual, sehingga pembelajaran matematika menjadi tidak menarik dan kurang memotivasi siswa, dan (2) Proses pembelajaran umumnya didominasi oleh ceramah dan dengan sedikit latihan. Guru terlalu terpaku pada buku teks, guru mengajar sesuai dengan buku teks, konsep diajarkan sesuai dengan alur yang terdapat pada buku teks, bahkan contohcontoh yang diberikan sebagai guru juga mengacu pada contoh yang tertulis pada buku teks. Kemampuan guru untuk mengembangkan materi pembelajaran masih terbatas, kegiatan-kegiatan pengayaan juga relatif terbatas.

Untuk mengatasi rendahnya hasil belajar matematika tersebut, perlu dilakukan perbaikan dalam hal pembelajaran. Penerapan model-model inovatif yang menempatkan siswa sebagai subjek belajar sudah harus diterapkan. Banyak model pembelajaran yang berpusat pada siswa (student centered learning) telah dikembangkan saat ini. Salah salah model diantaranya adalah model pembelajaran kooperatif tipe Student Facilitator and Explaining (SFE). Penelitian Zahra, dkk, (2016) dan Shoimin (2016) menunjukkan bahwa model ini memberikan dampak positif terhadap hasil belajar matematika siswa.

Penelitian ini selanjutnya diarahkan untuk mengkaji dampak penggunaan model pembelajaran kooperatif tipe Student Facilitator and Explaining (SFE) terhadap hasil belajar. Rumusan masalah penelitian ini adalah apakah terdapat perbedaan yang signifikan antara hasil belajar siswa kelas X SMA yang menggunakan model pembelajaran kooperatif tipe student facilitator and explaining (SFE) dan yang 
menggunakan model pembelajaran konvensional pada materi trigonometri.

\section{Metode Penelitian}

Tipe penelitian yang digunakan adalah tipe penelitian eksperimental (Experimental Research) dengan desain penelitian Post-Test Only Control Group Design. Populasi dalam penelitian ini adalah seluruh siswa kelas X IPA yang terdiri atas 3 (tiga) kelas. Sebagai sampel dipilih kelas $\mathrm{X}$ IPA1 dan X IPA3 yang memiliki kemampuan awal relatif sama, yakni rata-rata skor awal kelas X IPA1 adalah 69,47, sedangka rata-rata skor awal X IPA3 adalah 69,50.

Selanjutnya ditentukan kelas eksperimen dan kelas kontrol dengan cara mengundi. Terpilih Kelas X IPA1 sebagai kelas eksperimen dan kelas X IPA3 sebagai kelas kontrol. Kelas eksperimen diberikan pembelajaran menggunakan model pembelajaran kooperatif tipe Student Facilitator and Explaining (SFE), sedangkan kelas kontrol menggunakan model pembelajaran konvensional.

Dalam penelitian ini dikembangkan Rencana Pelaksanaan Pembelajaran (RPP) untuk masing-masing kelas. Untuk kelas eksperimen dikembangkan RPP sesuai model pembelajaran SFE untuk 4 (empat) pertemuan, demikian pula untuk kelas control dikembangkan RPP untuk 4 (empat) pertemuan dengan cakupan dan luasan materi yang sama. Selain itu dikembangkan pula lembar kerja siswa (LKS) dan bahan ajar trigonometri sesuai dengan kebutuhan penerapan model pembelajaran kooperatif tipe SFE. Juga dikembangkan instrumen tes yang digunakan untuk mengukur hasil belajar siswa pada kedua kelas.

Pelaksanaan pembelajaran pada masingmasing kelas, dilaksanakan mengacu pada RPP yang telah disusun dan divalidasi oleh pakar. Pada akhir kegiatan pembelajaran (setelah pertemuan keempat selesai) dilaksanakan tes kepada kedua kelas. Hasil tes selanjutnya dianalisis menggunakan analisis statistik deskriptif dan statistik inferensial. Sebelum dilakukan uji-t maka perlu dilakukan uji prasyarat sampel dengan menggunakan uji normalitas dan uji homogenitas. Data diolah dengan menggunakan bantuan software SPSS versi 20.0.

\section{Hasil dan Pembahasan}

\subsection{Analisis Deskriptif}

Pelaksanaan pembelajaran menggunakan model pembelajaran student facilitator and explaining pada kelas eksperimen dilaksanakan dalam 4 (empat) pertemuan. Setiap tahapan pembelajaran sesuai sintaks, berlangsung dengan baik dan lancar sesuai dengan yang direncanakan pada RPP. Aktivitas pembelajaran didukung dengan bahan ajar dan Lembar Kerja Siswa (LKS). Aktivitas siswa dalam kegiatan kelas maupun dalam kegiatan kelompok kecil ketika membahas materi pembelajaran dan mengerjakan LKS berlangsung dengan baik. Saat siswa bekrja dalam kelompok kecil mempelajari bahan ajar dan mengerjakan LKS, guru berjalan berkeliling memperhatikan aktivitas kelompok, dan memberikan bantuan penjelasan ketika kelompok mengalami kesulitan.

Pada kelas kontrol, yakni kelas yang menggunakan model pembelajaran konvensional, kegiatan belajar mengajar juga berlangsung selama 4 (empat) pertemuan. Pembelajaran dengan menggunakan buku siswa juga berlangsung dengan baik sesuai sintaks model pembelajaran konvensional.

Setelah pembelajaran dilakukan pada kedua kelas sesuai RPP untuk masing-masing kelas, pada pertemuan kelima dilakukan tes hasil belajar pada kedua kelas. Tes dilakukan menggunakan instrument yang sama yang telah dikembangkan sebelumnya. Adapun hasil tes pada masingmasing kelas adalah sebagai berikut:

Tabel 1. Hasil Belajar Siswa

\begin{tabular}{cccccc}
\hline \multirow{2}{*}{ Kualifikasi } & \multirow{2}{*}{ Nilai } & \multicolumn{2}{c}{ Kelas Eksperimen } & \multicolumn{2}{c}{ Kelas Kontrol } \\
& & $\mathrm{f}$ & $\%$ & $\mathrm{f}$ & $\%$ \\
\hline Sangat Baik & $90 \leq x$ & 2 & 6,25 & 0 & 0 \\
Baik & $75 \leq x<90$ & 8 & 25 & 4 & 13,33 \\
Cukup & $60 \leq x<75$ & 9 & 28,13 & 8 & 26,67 \\
Kurang & $40 \leq x<60$ & 9 & 28,13 & 10 & 33,33 \\
Sangat Kurang & $x<40$ & 4 & 12,50 & 8 & 26,67 \\
\hline
\end{tabular}


Dari tabel 1 di atas, terlihat bahwa pada kelas eksperimen terdapat 2 siswa $(6,25 \%)$ memiliki kemampuan sangat baik dan 8 siswa $(25,00 \%)$ dengan kemampuan baik. Sedangkan pada kelas kontrol hanya terdapat 4 siswa $(13,33 \%)$ yang memiliki kemampuan baik. Pada kelas eksperimen, terdapat 13 siswa (40,63\%) yang memiliki kemampuan kurang atau sangat kurang, sedangkan pada kelas kontrol, siswa dengan kemampuan kurang jauh lebih tinggi, yakni18 siswa $(60 \%)$. Dari perhitungan nilai rata-rata hasil belajar siswa kelas eksperimen dan kelas kontrol diperoleh hasil sebagaimana disajikan pada Tabel 2 berikut:

Tabel 2. Rata-rata Hasil Belajar Siswa

\begin{tabular}{lc}
\hline \multicolumn{1}{c}{ Kelas } & Rata-Rata \\
\hline Eksperimen & 64.41 \\
Kontrol & 52.00 \\
\hline
\end{tabular}

Tabel 2 di atas memperlihatkan bahwa nilai rata-rata siswa kelas eksperimen lebih tinggi bila dibandingkan dengan nilai rata-rata siswa kelas kontrol. Selisih nilai rata-rata kedua kelas juga relative tinggi, yakni sebesar 12,41. Dengan demikian, baik dari tabel 1 maupun tabel 2 di atas dapat disimpulkan bahwa pembelajaran dengan menggunakan model kooperatif tipe SFE memberikan hasil yang lebih baik bila dibandingkan dengan pembelajaran konvensional.

\subsection{Hasil Uji Hipotesis}

Sebelum dilakukan uji hipotesis komparatif, perlu dilakukan terlebih dahulu analisis prasyarat. Analisis prasyarat dimaksud adalah uji normalitas dan uji homogenits varians. Hasil uji normalitas hasil belajar pada kedua kelas menggunakan rumus Chi Square disajikan pada Tabel 3 berikut.

Tabel 3. Hasil uji Normaitas Data

\begin{tabular}{ccccc}
\hline Kelas & $\boldsymbol{x}_{\text {hitung }}^{\mathbf{2}}$ & $\boldsymbol{x}_{\text {tabel }}^{\mathbf{2}}$ & Sig. & Kes. \\
\hline $\begin{array}{c}\text { Eksperi } \\
\text { men }\end{array}$ & 12.0001 & 32.67056 & 0.940 & $\begin{array}{c}\text { Terima } \\
\mathrm{H}_{0}\end{array}$ \\
Kontrol & 8.6673 & 30.14351 & 0.979 & $\begin{array}{c}\text { Terima } \\
\mathrm{H}_{0}\end{array}$ \\
\hline
\end{tabular}

Tabel 3 di atas memperlihatkan bahwa pada kelas eksperimen, nilai $x_{\text {hitung }}^{2}=12.0001$, nilai $x_{\text {tabel }}^{2}=32.67056$ dan nilai Sig. $=0.940$. Karena $x_{\text {hitung }}^{2}<x_{\text {tabel }}^{2}$ dan Sig <0,05, maka disimpulkan bahwa hasil belajar kelas eksperimen berdistribusi normal. Dengan kata lain, kelas eksperimen berasal dari populasi yang berdistribusi normal. Tabel 3 juga memperlihatkan bahwa pada kelas kontrol nilai $x_{\text {hitung }}^{2}=8,667$, nilai $x_{\text {tabel }}^{2}=30,144$ dan nilai Sig. $=0.979$. Karena $x_{\text {hitung }}^{2}<x_{\text {tabel }}^{2}$ dan
Sig $<0,05$, maka disimpulkan bahwa hasil belajar kelas kontrol berdistribusi normal,

Selanjutnya dilakukan uji homogenitas untuk menentukan apakah kedua varians homogen ataukah tidak. Hasil pengujian dimaksud disajikan pada Tabel 4 berikut.

Tabel 4. Hasil uji Homogenitas Data

\begin{tabular}{ccccc}
\hline Kelas & $\boldsymbol{F}_{\text {hitung }}$ & $\boldsymbol{F}_{\text {tabel }}$ & Sig. & Kes. \\
\hline $\begin{array}{c}\text { Eksperimen } \\
\text { \& Kontrol }\end{array}$ & 1.1170 & 1.85 & 0.851 & $\begin{array}{c}\text { Terima } \\
\mathrm{H}_{0}\end{array}$ \\
\hline
\end{tabular}

Berdasarkan tabel diatas, terlihat bahwa nilai $F_{\text {hitung }}=1.1170$ lebih kecil dari nilai $F_{\text {tabel }}=1.85$ dan nilai Sig. $=0.851>0,05=$ $\alpha$. Dengan demikian $\mathrm{H}_{0}$ diterima $\mathrm{H}_{1}$ ditolak. Ini berarti bahwa kedua populasi memiliki varians yang homogen.

Karena data hasil belajar memenuhi ketentuan berdistribusi normal dan ketentuan homogenitas varians, maka dapat dilanjutkan dengan uji t, sebagai salah satu uji statistik inferensial. Hasil uji dimaksud dapat disajikan pada Tabel 5 berikut.

Tabel 5. Hasil uji Hipotesis

\begin{tabular}{lcccc}
\hline Kelas & $\boldsymbol{t}_{\text {hitung }}$ & $\boldsymbol{t}_{\text {tabel }}$ & $\begin{array}{c}\text { Sig.(2- } \\
\text { tailed) }\end{array}$ & Kes. \\
\hline $\begin{array}{l}\text { Eksperimen } \\
\text { \& Kontrol }\end{array}$ & 3.1128 & 2.0003 & 0.0002 & $\begin{array}{c}\text { Terima } \\
\mathrm{H}_{1}\end{array}$ \\
\hline
\end{tabular}

Tabel 5 di atas memperlihatkan bahwa nilai $t_{\text {hitung }}=3.1128$ lebih besar dari nilai $t_{\text {tabel }}=$ 2.0003; dan nilai Sig. $=0,002$ kurang dari nilai $\alpha=0.05$. Dengan demikian, dapat disimpulkan bahwa terdapat perbedaan yang signifikan antara hasil belajar siswa yang menggunakan model pembelajaran kooperatif tipe Student Facilitator and Explaining (SFE) dan model pembelajaran konvensional.

\subsection{Pembahasan}

Model pembelajaran Student Facilitator and Explaining (SFE) yang dikaji dalam penelitian ini memiliki 6 tahap atau langkah sesuai dengan pendapat Shoimin (2016) meliputi: (1) Guru menyampaikan materi yang akan dipelajari dan kompetensi yang ingin dicapai, (2) guru mendemonstrasikan atau menyajikan garis-garis besar materi pembelajaran, (3) memberikan kesempatan kepada siswa untuk menjelaskan kepada siswa lainnya, dengan menggunakan bahan ajar atau buku siswa, (4) guru menyimpulkan ide atau pendapat dari siswa, (5) guru menerangkan semua materi yang disajikan saat ini, dan (6) penutup. 
Pada kelas yang menggunakan model Student Facilitator and Explaining (SFE), siswa terlihat aktif dalam proses pembelajaran. Siswa aktif mempelajari bahan ajar, aktif mengerjakan LKS, aktif berdiskusi dan berbagi kepada temannya, siswa terlibat secara aktif dalam merancang materi pembelajaran yang akan dipresentasikan, dan siswa aktif mengkomunikasikan pikirannya dan hasil kerja kelompoknya. Kondisi seperti ini tentunya akan berdampak pada iklim belajar yang lebih baik. Siswa dapat saling belajar dari teman-temannya, dan siswa pandai terkondisi untuk menjelaskan materi kepada teman-temannya.

Dalam setting belajar kooperatif, siswa cenderung lebih terbuka dan mau bertanya kepada temannya yang lebih memahami materi. Interaksi antar siswa juga berkembang sangat baik. Siswa mungkin agak malu atau segan bertanya pada gurunya, tetapi dalam pembelajaran kooperatif, termasuk pada tipe SFE, siswa dapat lebih bebas bertanya dan berdiskusi dengan teman kelompoknya. Menurut Ratumanan (2019), di dalam setting kooperatif, intensitas interaksi menjadi lebih besar. Kenyataan menunjukkan bahwa dalam setting kelas, peserta didik lebih banyak belajar dari satu teman ke teman lainnya di antara sesama peserta didik dari pada belajar dari guru.

Interaksi yang terbangun secara dinamis dalam pembelajaran kooperatif, termasuk pada tipe SFE ini akan juga mendukung pengembangan kemampuan komunikasi matematika sebagai salah satu kompetensi yang harus ditumbuhkembangkan melalui pembelajaran matematika. Hal ini sesuai dengan pendapat dari Suprijono (2009), bahwa model pembelajaran Student Facilitator and Explaining (SFE) merupakan model pembelajaran dimana siswa mempresentasikan ide/pendapat pada siswa lainnya. Model pembelajaran ini efektif untuk melatih siswa berbicara menyampaikan ide/gagasan atau pendapatnya sendiri.

Pembelajaran kooperatif tipe SFE juga akan memberikan manfaat besar bagi pemahaman atau penguasaan materi pembelajaran. Melalui belajar dan berdiskusi bersama dan/atau mengikuti penjelasan, penguasaan siswa terhadap materi akan lebih baik. Siswa pandai juga akan menerima manfaat dari setting belajar seperti ini; dengan memberikan penjelasan kepada temannya di dalam kelompok atau presentasi materi pada kelompok besar (kelas), siswa telah melakukan pengulangan mempelajari materi pembelajaran. Hal ini akan memberikan dampak pengetahuan matematika tidak lagi tersimpan pada memori jangka pendek (short term memory), tetapi sudah tersimpan di memori jangka panjang (long term memory). Ratumanan (2019), menjelaskan bahwa dalam setting kooperatif, siswa dalam setiap kelompok kecil akan bekerja sama, saling membantu dan saling melengkapi, baik dalam mempelajari bahan ajar, maupun dalam menyelesaikan tugas-tugas kelompok. Dengan kondisi ini dapat diharapkan materi yang dibahas akan dapat dipahami secara lebih baik, juga tugastugas (aktivitas atau pemecahan masalah) yang dihadapi dapat diselesaikan dengan baik.

Pada kelas kontrol yang diajarkan dengan menggunakan model pembelajaran konvensional, guru aktif menjelaskan materi disertai contoh soal untuk setiap bagian yang dijelaskan. Sedangkan siswa relative pasif dalam kegiatan pembelajaran; siswa hanya memperhatikan dan mencatat apa yang dijelaskan. Pada setiap sub pokok bahasan yang dijelaskan, guru memberikan kesempatan kepada siswa untuk bertanya. Pada kesempatan ini, terdapat beberapa siswa yang mengajukan pertanyaan. Untuk setiap pertanyaan siswa, guru memberikan penjelasan dan membuat catatan di papan tulis.

Setelah setiap konsep disertai contoh dijelaskan, guru memberikan soal sesuai konsep tersebut untuk dikerjakan siswa. Hal ini diaksudkan untuk memperkuat pemahaman siswa terhadap materi atau konsep yang telah dijelaskan. Dalam menyelesaikan soal latihan tersebut, para siswa cenderung bekerja secara individual, walaupun terdapat beberapa siswa yang mencoba berdiskusi dengan teman sebelahnya. Setelah siswa selesai mengerjakan soal, guru meminta salah seorang siswa untuk mengerjakannya di depan kelas. Kemudian guru memberikan kesempatan kepada siswa lain untuk memberikan respons terhadap hasil kerja tersebut.

Guru memberikan materi sesuai dengan buku yang telah dipelajari. Interaksi antara guru dan siswa, serta interaksi antarsiswa relatif terbatas. Dalam proses pembelajaran, siswa relatif pasif, dan lebih banyak menjadi pendengar atau pencatat penjelasan guru. Hal ini sesuai dengan pendapat Sukardi (dalam Kholik, 2011), bahwa pembelajaran konvensional ditandai dengan guru lebih banyak mengajar tentang konsep-konsep bukan kompetensi, tujuannya adalah siswa mengetahui sesuatu bukan mampu untuk melakukan sesuatu dan pada saat proses pembelajaran siswa lebih banyak mendengarkan.

Keterlibatan siswa secara aktif dalam memproses dan mengkonstruksi konsep trigonometri dalam pembelajaran menggunakan 
model pembelajaran kooperatif tipe SFE memberikan dampak yang lebih baik pada tingkat pemahaman dan daya serap siswa. Walaupun tidak semua siswa dapat berkembang lebih baik dan masih terdapat sekitar $40,63 \%$ siswa dengan tingkat penguasaan materi trigonometri dalam kategori rendah atau sangat rendah, tetapi hasil analisis menunjukkan bahwa hasil belajar kelompok SFE jauh lebih baik bila dibandingkan dengan siswa yang mengikuti pembelajaran menggunakan model konvensional.

Dari analisis hipotesis menggunakan uji $\mathrm{t}(\mathrm{t}-$ test) diperoleh bahwa $t_{\text {hitung }}=3,1128>$ $t_{\text {tabel }}=2,0003$, yang berarti bahwa perbedaan hasil belajar berkaitan dengan penggunaan kedua model pembelajaran adalah signifikan. Dengan kata lain, hasil belajar trigonometri yang diperoleh melalui penggunaan model pembelajaran kooperatif tipe SFE secara signifikan lebih baik bila dibandingkan dengan model konvensional. Hasil penelitian ini relevan dengan penelitian dari Zahra, dkk (2016) yang menyatakan bahwa dengan menggunakan model pembelajaran student facilitator and explaining, semua kategori spasial kecerdasan spasial siswa tinggi, sedang, dan rendah memberikan efek yang berbeda terhadap prestasi belajar matematika siswa.

\section{Kesimpulan}

Berdasarkan hasil penelitian yang telah dideskripsikan di atas, dapat disimpulkan bahwa terdapat perbedaan yang signifikan antara hasil belajar siswa kelas X SMA yang menggunakan model pembelajaran kooperatif tipe Student Facilitator and Explaining (SFE) dan model pembelajaran konvensional pada materi trigonometri. Hasil belajar trigonometri dari siswa yang mengikuti pembelajaran menggunakan model pembelajaran kooperatif tipe Student Facilitator and Explaining (SFE) lebih baik bila dibandingkan dengan yang menggunakan pembelajaran konvensional.

\section{Daftar Pustaka}

Andriani, T, Suastika. K, \& Sesanti, N. R. (2017). Analisis Kesalahan Konsep Matematika Siswa Dalam Menyelesaikan Soal Trigonometri Kelas $\mathrm{X}$ TKJ SMK N 1 Gempol Tahun Pelajaran 2016/2017. Mathematics Education Journal, Vol 1. 35-37.

Jingga. A. A, Mardiyana, \& Setiawan, R. (2017). Analisis Kesalahan Siswa Dalam Menyelesaikan Soal Identitas Trigonometri
Kelas X Semester 2 SMA Negeri 1 Kartasura Tahun Ajaran 2015/2016. Jurnal Pendidikan Matematika dan Matematika, Vol I. No.5: 5457.

Kholik. (2011). Pembelajaran Konvensional. http://www.metodepembelajaran. com (diakses tanggal 04 Maret 2019)

Ratumanan, T. G. 2015. Belajar dan Pembelajaran. Yogyakarta: Pensil Komunika.

Ratumanan, T. G \& Theresia Laurens. 2016. Analisis Penguasaan Objek Matematika (Kajian pada Lulusan SMA di Provinsi Maluku). Jurnal Pendidikan Matematika Raflesia. Vol. 1 No. 2 Desember 2016.

Ratumanan, T. G., \& Christy Matitaputty. 2018. Belajar dan Pembelajaran Matematika. Bandung: Alfabeta.

Ratumanan, T. G., \& Carolina S. Ayal. 2018. Problem Solving Based Learning Model Alternative Model of Developing High Order Thinking. International Journal of Health Medicine and Current Research Vol. 3, Issue 02, pp.857-865, June, 2018.

Ratumanan, T. G. 2019. Model Pembelajaran Interaktif dengan Setting Kooperatif (Model PISK). Bandung: Alfabeta.

Rusman. (2011). Model-Model Pembelajaran Mengembangkan Profesionalisme Guru. Jakarta : PT Raja Grafindo Persada

Shoimin, A. (2016). 68 Model Pembelajaran Inovatif dalam Kurikulum 2013. Yogyakarta: Ar-Ruzz Media

Suprijono, A. (2009). Cooperative Learning. Yogyakarta: Pustaka Belajar.

Susanto, A. (2014). Teori Belajar dan Pembelajaran di Sekolah Dasar. Jakarta

Zahra. C, Widyawati. S, \& Ningsih, E. F. (2016). Eksperimentasi Model Pembelajaran Kooperatif Tipe Student Facilitator and Explaining (SFE) Berbantuan Alat Peraga Kotak Imajinasi Ditinjau Dari Kecerdasan Spasial. Jurnal Ilmiah Pendidikan Matematika, Vol 2. 97-98 